\title{
Development of Human Capital in the Cross- Multidimensional Space of the Russian Metropolis
}

\author{
Donina I.A. \\ Yaroslav-the-Wise Novgorod State University, \\ Veliky Novgorod, Russia, \\ doninairina@gmail.com
}

\author{
Elistratova K.A. \\ State budgetary educational institution lyceum No. 101 \\ St. Petersburg, Russia \\ xenos88@mail.ru
}

Panasyuk V.P.

St. Petersburg Academy of Postgraduate Pedagogical Education,

St. Petersburg, Russia,

panasykvpqm@mail.ru

\begin{abstract}
The article presents the concept of human capital development in relation to a Russian metropolis, a multidimensional description of its formative potential. Among the main components of the Russian metropolis crossmultidimensional space digital, social, economic, technological, information, innovative, cultural and historical, ethnocultural, subject-spatial, axiological, production and professional environments; geographical, humanitarian, biblio-media, network, semantic, noospheric and event spaces intersecting and interacting in various combinations are considered. Based on the content analysis methodology, the authors have determined the quantitative and qualitative parameters of some of these spaces and environments representation in a large St. Petersburg's edition as factors of the human capital formation and development in relation to this Russian metropolis. A separate article's aspect is related to the issues of separate spaces and environments interaction and intersection in various combinations in the context of considering the human capital formation problem. The article also discusses the results of a study related to determining the nature and saturation of various spaces and environments of one of the major St. Petersburg's city highways. Among the modern trends in the human capital development in relation to a Russian metropolis, the authors of the article distinguish and analyze various cross-multidimensional combinations of spaces and environments, the active use of engineering and socio-pedagogical technologies, a prospective approach and humanitarian design; creating learning communities and intellectual collaborations; modernizing traditional education, upbringing and socialization institutions; leveraging the potential of artificial intelligence and digital tools within open and flexible educational ecosystems.
\end{abstract}

Keywords-globalization, cross-multidimensional space, technologies, digitalization, human capital, ecosystem

\section{INTRODUCTION}

The modern world is characterized by complexity, manufacturability, cultural mosaicism and makes high demands on humans.
The XXI century personalities should have not only professional and social competencies, but also a willingness to choose individual development trajectories, value selfdetermination and use the potential of the external sociocultural environment.

If we are talking about a large Russian metropolis, then it is important that in the space of its culture and education, urban, industrial and technological environment, a universal personality with a multifaceted vision and reflection of the world and a multifunctional thesaurus of knowledge, skills, abilities and competencies is formed and improved.

Taking this into account, it is relevant to conduct a study related to the main trends establishment, the influence of factors of cross-multidimensional spatial-environmental ecosystems on the formation and development of human capital in relation to the Russian metropolis.

\section{Problem Statement}

Human capital will be the main source for the further Russia's development in the second quarter of the XXI century, as an intangible asset, a set of knowledge, skills, competencies, personal characteristics of the adult population representatives employed in the social production sphere, acquired, formed and improving both in the field of education and upbringing, and in the field of professional use directly.

Due to this, the issue of all social institutions integrated resources (education, health care, social protection, public organizations, mass communications) allocated for education (including job training), upbringing, enlightenment, health protection, ultimately, they worked to increase human capital and its renewal in accordance with social needs [1, 2].

Despite the processes of globalization and digitalization [3, $4,5,6]$, it can be assumed that the processes of human capital formation and development are largely localized and confined to certain resources and potential. In this regard, St. Petersburg, which is not only one of the Russian metropolises, but also a 
large cultural, educational, industrial-innovative, business and administrative centre, not only in Russia, but also in Europe, has got into the field of our research interest.

Therefore, the key problem being solved in this article is the problem of combining the key elements of the metropolis crossmultidimensional space with the processes of human potential formation and development in the ecosystem approach logic.

\section{RESEARCH QUESTIONS}

A lot of studies have been devoted to the human capital formation and development; a significant number of publications on this topic appear every year. It is believed that investment in human capital is many times offset by an increased income stream in the future [7], in the information economy, human capital is largely transformed, its structure is changing $[8,9,10]$, active efforts are required to manage the processes of human capital formation [11], it is said about the need to manage human capital in the workplace [12], to manage investments in the organization's human capital [13], to invest in human capital, in the non-cognitive skills development (especially in children), making an important part of individual human capital.

In this regard, ideas, developments and models proposed by ideologists and authors of works in the field of ecosystems may be in demand $[14,15]$.

Therefore, considering the theory status, questions which require study and analysis can be posed:

- how the individual spaces and environments specified in the introduction fit into the ecosystem of human capital formation in the Russian metropolis;

- what are the trends in the human capital formation in cross-multidimensional ecosystems;

- what is the nature of the interaction and what options of intersection can potentially have a positive impact on the human capital formation.

\section{PURPOSE OF THE STUDY}

The aim of the study was to identify the main trends and key factors of the human capital formation and development in the cross-multidimensional space of the Russian metropolis as a developing ecosystem.

\section{RESEARCH METHODS}

To achieve the goal of the study, we used research methods for the human capital formation in the cross-multidimensional space of the Russian metropolis. Methods of theoretical analysis, synthesis and generalization, as well as empirical methods (content analysis, survey, observation) were chosen. The sources for the theoretical analysis were a number of articles and monographs from the field of pedagogy, psychology, economics, philosophy, sociology and normative legal acts.

\section{FINDINGS}

Solving the empirical problems of the research, we have carried out a content analysis of the St. Petersburg Government official daily newspaper "The Petersburg's Diary" (10 issues in total), with a 160 thousand copies circulation, concerning the individual spaces and environments representation in its materials, and the degree of their interaction and intersection.

Content analysis has made it possible to establish the degree of certain spaces and environments representation in newspaper materials (see Table I) so that it was possible to determine the key factors of the human capital formation and development.

TABLE I. CONTENT ANALYSis DATA OF THE ST. Petersburg GOVERNMENT'S DAILY OFFICIAL NEWSPAPER, "THE PETERSBURG'S DIARY" (ISSUES DATED 02/07; 03/07; 06/07; 07/07; 08/07; 09/07; 10/07; 13/07; 14/07; $15 / 07.2020)$

\begin{tabular}{|c|c|c|c|}
\hline No. & Spaces and environments & $\begin{array}{c}\text { Number of } \\
\text { newspaper } \\
\text { issues in which } \\
\text { this or that } \\
\text { environment or } \\
\text { space is } \\
\text { presented }\end{array}$ & $\begin{array}{c}\text { Presentation } \\
\text { intensity } \\
\text { (number of } \\
\text { materials) }\end{array}$ \\
\hline 1 & $\begin{array}{l}\text { Political environment. } \\
\text { Public life sphere }\end{array}$ & 8 & 12 \\
\hline 2 & Social environment & 5 & 11 \\
\hline 3 & Cultural environment & 7 & 21 \\
\hline 4 & $\begin{array}{l}\text { Ecological space. Habitat } \\
\text { safety }\end{array}$ & 7 & 8 \\
\hline 5 & $\begin{array}{l}\text { Museum, architectural } \\
\text { space }\end{array}$ & 9 & 14 \\
\hline 6 & Living environment & 8 & 20 \\
\hline 7 & Technological environment & 2 & 2 \\
\hline 8 & Educational space & 5 & 7 \\
\hline 9 & $\begin{array}{l}\text { Digital, virtual environment } \\
\text { (cyberspace) }\end{array}$ & 3 & 3 \\
\hline 10 & Axiological space & 6 & 6 \\
\hline 11 & $\begin{array}{l}\text { Information space (facts; } \\
\text { TV program; weather) }\end{array}$ & 10 & 17 \\
\hline 12 & $\begin{array}{l}\text { Biblio-media space } \\
\text { (including cinema) }\end{array}$ & 5 & 5 \\
\hline 13 & $\begin{array}{l}\text { Historical and cultural } \\
\text { space }\end{array}$ & 4 & 4 \\
\hline 14 & $\begin{array}{l}\text { Industrial and professional } \\
\text { environment }\end{array}$ & 6 & 8 \\
\hline 15 & Valeological space & 7 & 14 \\
\hline 16 & Criminal space & 10 & 30 \\
\hline 17 & $\begin{array}{l}\text { Professional sport } \\
\text { environment }\end{array}$ & 10 & 25 \\
\hline 18 & $\begin{array}{l}\text { Symbolic environment. } \\
\text { Monuments, memorials }\end{array}$ & 3 & 4 \\
\hline 19 & Innovative environment & 3 & 3 \\
\hline \multirow[t]{2}{*}{20} & $\begin{array}{l}\text { Economic environment. } \\
\text { Business environment }\end{array}$ & 6 & 12 \\
\hline & $\begin{array}{c}\text { Total: } \\
\end{array}$ & 124 & 226 \\
\hline
\end{tabular}

As it follows from the Table 1, the most represented in newspaper materials among separate spaces and environments are the following ones: criminal space (10 issues / 30 materials); professional sport environment (10/25); information space 10/17); museum, architectural space (9/14); living environment (8/20); cultural environment (7/21). These 6 spaces and environments account for a total of $56.2 \%$ of all materials contained in 10 issues of the newspaper selected for analysis. There is an obvious bias towards the coverage of areas that are little or not at all related to the human potential formation of the Russian metropolis (criminal space; professional sport environment)

The analysis has also shown that when covering events, phenomena and processes, a number of spaces and environments, directly related to the formation of conditions for 
the human potential development in new technological conditions (digital, virtual environment, cyberspace - 3 newspaper issues / 3 materials; innovative environment $-3 / 3$; technological environment $-2 / 2$ ), are unjustifiably ignored.

When conducting a quantitative analysis of the representation degree in the materials of the St. Petersburg Government's official publication, the "The Petersburg Diary" newspaper, one should bear in mind the peculiarities of the city itself, not only as a Russian metropolis, but also as a large historical and cultural centre of world significance with a rich history, traditions and heritage. In this regard, it can be noted that this issue is reflected quite fully and versatile. Quantitatively, it looks like this: cultural environment (7/21); museum, architectural space (9/14); historical and cultural space (4/4); symbolic environment. Monuments and memorials (3/4). Summarily expressed, this accounts for $19.0 \%$ of the total published materials volume.

Concluding the analysis of various spaces and environments presentation intensity in "The Petersburg Diary" newspaper which influence the human capital formation in the Russian metropolis, one cannot fail to note the insufficient attention in the edition's editorial policy to the educational one (only 7 publications in 5 issues; $3.1 \%$ of all publications), axiological (6 publications in 6 issues in total; $2.7 \%$ of all publications) and biblio- media spaces (5 publications in 5 issues in total; $2.2 \%$ of all publications). It should be noted that publications on educational issues were largely situational in nature and were associated with the period when graduates of secondary schools passed the Unified State Exam.

The potentially high efficiency of covering the abovementioned spaces and environments in terms of the human capital formation and development should also be noted. This is quite evident on the example of the biblio-media space presentation in the newspaper issue dated July 3, 2020. One of the newspaper pages was devoted to acquainting readers with a joint project of "The Petersburg Diary" newspaper and the Writers' Union of St. Petersburg. In particular, there are two short materials from one of the writers working in the genre of a fantastic detective story.

A separate issue of the study was related to the determination of how individual spaces and environments intersect and interact with each other, creating conditions for the human capital formation and development. Below are just eight of these examples.

In the article "Were the Seals Scared of Kites over the Gulf of Finland?" in the newspaper dated July 3, 2020; environmental issues are supplemented with a cultural component, when the authors of the material inform readers about the relatively young "kitesurfing" sport; include an axiological context when it comes to civic position and value attitudes of this sport's representatives.

In the publication "Jubilee of the Champion and the Artist" in the newspaper dated July 3, 2020 the problem of elite sports (on the example of the biography of the first ever Olympic winner from the USSR and Leningrad - St. Petersburg, Yu. Tyukalov) is supplemented with a historical, cultural and axiological context, when it comes to the tragic days of the siege and defense of Leningrad during the Great Patriotic War and the athlete's patriotism.

Although the article "Victory Arch in Krasnoe Selo Awaits
Repair and Illumination" in the newspaper dated July 6, 2020 contains a description of the problem of repairing the monument, it also contains an axiological element. The article "Between music and work is not a line, but a huge moat" dated July 7, 2020 presents a biography and achievements in the professional field and musical work of a young surgeon at the city hospital of St. George, Alexander Lomia. The material actually presents the intersection and interaction of the professional-industrial environment, axiological space (the hard work of a young man, his respect and gratitude to his parents, love for the profession of a doctor), valeological and cultural space (passion for music, writing songs in the rap genre, participation in music competitions) ... In the interview "I Have Always Done My Work as Honestly as Possible" dated July 8, 2020 St. Petersburg theater and film actor Dmitry Lysenkov talks about the difficulties of a theatrical life and about his personal creative plans in movies. The article "Screen on Wheels": How the Drives-Ins Work" dated July 8, 2020 clearly shows the intersection of cultural space with innovative and technological environments. In the article "Lenfilm is Preparing to Take Four Important Steps" dated July 10, 2020, the description of the Lenfilm film studio's financial recovery program is combined with cultural issues when it comes to the intention to implement a project to create an educational cultural center based on Lenfilm. In the material dated July 14, 2020, "Vandals Have Cut Venus Fingers Off", one can trace the intersection of the criminal, historical, cultural and axiological spaces.

Therefore, among the main trends, it can be noted that when materials are presented, there are tendencies for a crossmultidimensional combination of various spaces and environments.

\section{CONCLUSION}

The conducted research confirms the importance of understanding the mechanisms and modern trends in the human capital formation and development in the conditions of the Russian metropolis. Formed within its borders, various spaces and environments have unique properties, when intersected and interacted, serve as powerful factors in the formation of people's culture, mentality, values and educational potential, which is thus the human capital of a city or country, determines their competitiveness, development vectors and pace in the global world.

\section{References}

[1] A. Timofeev, O. Lebedinskaya, E. Yarnykh, and M. Kournikova, The Influence Of Human Capital Development On National Innovative Potential, The European Proceedings of Social \& Behavioural Sciences, 2019, pp. 198-205. DOI: 10.15405/epsbs.2019.04.23

[2] D. Saralinova, Human potential in the context of the realities of modern education [Chelovecheskiy potentsial v kontekste realiy sovremennogo obrazovaniya], Economy and entrepreneurship, 2015, vol. 12-1(65), pp. 682-685. (In Russ.)

[3] L. Sazhneva, I. Borisova, and M. Kivarina, "Integration of higher education and digital economy development", The European Proceedings of Social \& Behavioural Sciences, 2019, pp. 8-16. DOI: https://doi:10.15405/epsbs.2019.04.2

[4] S. Shmanev, and L. Shmaneva, "Investments in human capital in the modernization of the real sector of the economy", The European Proceedings of Social \& Behavioural Sciences EpSBS, 2018, pp. 836842. DOI: $10.15405 /$ epsbs.2019.04.90 
[5] B. Michael, R. Michael, and R. Fuller, (2020) "Matching learning conditions to explicit knowledge characteristics: informing employersupported investments in individual human capital", Human resource development international

DOI: https://doi.org/10.1080/13678868.2020.1753448

[6] R. del R. L.E. Lami, R.V. del C. Guirado, and G.J.L. Leon, "The learning in the virtual communities", Revista conrado, 2020, vol. 74(16), pp. 261-265.

[7] Yu. Kobzistaya, "Human capital: concept and features" [Chelovecheskiy kapital: ponyatiye i osobennosti], Journal of Fundamental Research, 2018, vol. 2, pp. 118-122. (In Russ.).

[8] S. Zvezdina, (2017) Transformation of human capital into intellectual capital in the information economy [Transformatsiya chelovecheskogo kapitala v intellektual'nyy kapital v informatsionnoy ekonomike, Penza: Publishing house Science and Education, 2017. (In Russ.).

[9] Zh. Hou, M. Jin, and S.C. Kumbhakar, "Productivity spillovers and human capital: A semiparametric varying coefficient approach", European journal of operational research, 2020, vol. 287(1), pp. 317-330.

[10] L. Sinay, R.V. Carter, and M.C.F. de Sinay, "In the race for knowledge, is human capital the most essential element?", Humanities \& social sciences communications, 2020, vol. 7(20), pp. 1-7. Retrieved from https://www.nature.com/articles/s41599-020-0521-5.pdf
[11] E. Zadorozhnyaya, Human capital in the CIS countries [Chelovecheskiy kapital v stranakh SNG], SPb: Publishing house of Peter the Great St. Petersburg Polytechnic University, 2017. (In Russ.)

[12] M. Mustafaev, and E. Shatskaya, Development of human capital as the basis of the company's intellectual capital [Razvitiye chelovecheskogo kapitala kak osnovy intellektual'nogo kapitala kompanii], Simferopol. Arial, 2020.

[13] I. Krakowska, Development of theory and methodology for managing investments in human capital in the context of innovative development of the organization [Razrabotka teorii i metodologii upravleniya investitsiyami $\mathrm{v}$ chelovecheskiy kapital $\mathrm{v}$ usloviyakh innovatsionnogo razvitiya organizatsii], Moscow: MSTU im. N.E. Bauman, 2011.

[14] Ch. Linder, Ch. Lechner, and F. Pelzel, "Investments in human capital in the modernization of the real sector of the economy", Entrepreneurship theory and practice, 2020, vol. 5(44), pp. 909-932.

[15] B. Oleinikov, and S. Podlesny, On the concept of the "Learning Ecosystem" and directions of development of informatization of education [O kontseptsii «Ekosistema obucheniya» i napravleniyakh razvitiya informatizatsii obrazovaniya], Knowledge. Understanding. Skill, 2013, vol. 4, pp. 84-91 